\title{
A disparada do burro e a cartilha do feitor: lógicas morais na construção de redes de sociabilidade entre escravos e livres em fazendas do Sudeste, 1860-1888 ${ }^{1}$
}

\author{
L uiz A lberto Couceiro \\ M estrando do Programa de Pós-G raduação em \\ Sociologia e A ntropologia - IFCS/ UFRJ
}

\begin{abstract}
RESUMO: O objetivo principal do autor é pensar as relações de trabalho entre senhores, escravos, lavradores, administradores e feitores, em fazendas de café do Sudeste, nas décadas finais da escravidão. Para isso, tais relações sociais são analisadas através de dois estudos de caso, nos quais se chama a atenção para o conflito entre homens livres e escravos na formação de alianças em torno das regras sociais de justiça e trabalho, as quais são constantemente rompidas e reafirmadas, em permanente conflito social.
\end{abstract}

PALAVRAS-CHAVE: antropologia da escravidão; emancipação; política escrava; sociabilidade em fazendas.

\section{Introdução: inflexões políticas em fazendas de café no Sudeste escravista}

Na segunda metade do século XIX, o Vale do Paraíba e a região do O este paulista foram as áreas econômicas mais importantes do Império do Brasil, graças à próspera produção de café para os mercados externos. 
Também nesse mesmo período as pressões internacionais para o fim do tráfico de escravos para o Brasil intensificaram-se, principalmente após a Lei Eusébio de Queiroz, em 1850, que proibia de vez tal comércio (Conrad, 1978; Rodrigues, 2000). Um aparente paradoxo se dava com a necessidade que os fazendeiros de café daquelas áreas do Sudeste tinham de mais braços para o trabalho nas lavouras, cada vez maiores, e com a impossibilidade da mão-de-obra escrava ser adquirida por meio do comércio externo, como tradicionalmente era feito. Uma vez terminado 0 tráfico intercontinental de escravos, a reposição dessa mãode-obra estava comprometida, ou melhor, eliminada, pois seu preço subiu rapidamente. Nas províncias do Sul, Rio de Janeiro - Vale do Paraíba - e São Paulo - região O este - a expansão do café exigia dos senhores maior quantidade de trabalhadores, de modo a produzir mais para ganhar mais, pois o produto era perecível e de cultivo delicado. Logo, o tráfico inter-regional de escravos tornou-se um grande negócio, tanto para quem vendia - pequenos proprietários em decadência - quanto para quem comprava - donos de grandes faixas de terras e escravarias, que precisavam de mais trabalhadores para aumentar a produção (Costa, 1989, p. 91-98).

A cada ano aumentava o número de escravos nascidos no Brasil, em relação aos nascidos na África, e os cafeicultores conseguiam empréstimos proporcionais ao número de escravos que possuíam, pois davam a escravaria como garantia aos bancos, que teriam, assim, maior probabilidade de retorno financeiro. D essa forma, bancos emprestavam dinheiro a prazos longos - 15 anos - e sob condições bem favoráveis aos senhores de escravos e cafeicultores do Sudeste. A partir de 1870, iniciou-se uma intensa movimentação de compra e venda de escravos, porque vários cafeicultores acreditavam na queda dos lucros advindos do café, pois as terras estavam cada vez mais esgotadas para renderem safras da qualidade exigida para exportação. Segundo esse raciocínio, ou me- 
Revista de Antropologia, São Paulo, USP, 2003, v. 46 № 1.

lhor, estimativa, certos cafeicultores escravistas estipulavam um tempo para lucrar o máximo que pudessem com sua mercadoria; para tal, necessitavam cada vez mais da mão-de-obra escrava para intensificar a produção. Preparavam-se para o final da escravidão no Brasil, pois quanto mais rápido lucrassem com o café, mais rápido teriam o retorno financeiro do grande investimento que haviam feito na compra dos escravos necessários (Slenes, 1986). Tal aposta baseava-se nos debates políticos da época acerca do final da escravidão no Brasil e no entendimento de como seria administrada a abolição (Q ueiroz, 1981), o que levou tais cafeicultores à aquisição de um número máximo possível de escravos num curto espaço de tempo. D efinitivamente, o escravo havia se tornado a mais cara "mercadoria" nessas terras.

D o ponto de vista dos senhores envolvidos na produção de café e açúcar, o preço real do escravo efetivamente havia aumentado depois do final do tráfico internacional, em 1850, com a mão-de-obra cativa permanecendo lucrativa (Slenes, 1986; Mattos, 1990, p. 99-100). Se, por um lado, esse quadro criou condições mais severas de exploração dos escravos pelos senhores - por exemplo, a redução drástica do número de alforrias aos cativos, bem como do número de dias santos católicos reconhecidos como dias de descanso (Silva, 1989, p. 68) -, por outro, há dados que apontam para políticas de afrouxamento no trabalho dos africanos novos, em contrapartida ao dos ladinos e crioulos, principalmente os imigrados das províncias do Norte do Império. ${ }^{2}$

D essa forma, depois de 1850, houve uma quebra de "acordo" entre escravos e senhores, elaborado no período anterior ao final do tráfico, ${ }^{3}$ posto que, com o final do tráfico, os africanos novos desapareceram ${ }^{4}$ ao mesmo tempo que, com a intensificação do tráfico interno, justamente os escravos antes privilegiados pelos senhores - africanos ladinos e crioulos - eram vendidos das propriedades onde trabalhavam, quando esperavam ver recompensadas suas estratégias de aproximação com seus 
senhores. As imigrações forçadas de escravos através do tráfico tinham como destino, na maioria dos casos, as fazendas de café do Sudeste, onde tais escravos passaram a ser tratados como verdadeiros estrangeiros. ${ }^{5}$

Por um lado, o efeito econômico fora positivo para os cafeicultores escravistas do Vale do Paraíba e O este paulista, por outro, o efeito psicossocial fora negativo. D esde a insurreição malê, em 1835, quando escravos muçulmanos tomaram o centro da cidade de Salvador, ${ }^{6} \mathrm{em}$ confronto armado com forças policiais (Reis, 1986), as autoridades imperiais e os membros da "boa sociedade imperial" temiam que grandes concentrações de escravos pudessem gerar insurreições de proporções avassaladoras, entendendo que o medo paranóico era fruto, nesse caso, de conflitos sociais verossímeis (Azevedo, 1987). Esse "medo branco das ondas negras" alimentou as regras de sociabilidade dos senhores com seus escravos, e vice-versa, informando como deviam agir os administradores das fazendas e os feitores, não somente com relação aos escravos africanos, velhos ou novos, que já estavam naquelas fazendas de café, mas também com relação aos escravos que chegavam das províncias do Norte. O s modos de agir das pessoas na fazenda tanto poderiam sofrer abalos com a chegada de tais trabalhadores, como poderiam forçá-los a seguir as regras de relações sociais ali estabelecidas entre os escravos - no bojo das uniões e querelas internas ao grupo - , entre os escravos e 0 feitor, 0 administrador, o senhor e outros homens livres, não somente em questões relativas ao grupo, como em questões particulares de um ou mais escravos. ${ }^{7}$

Como nem sempre os senhores permaneciam muito tempo em suas fazendas, em muitas ocasiões, o administrador da fazenda assumia a frente não somente das questões materiais, mas também das emoções dos trabalhadores. Com isso estamos longe de pensar, o que seria inverossímil, que tais senhores fossem absenteístas, relapsos em relação à sua produção e aos acontecimentos de sua(s) fazenda(s). Lembramos "apenas" 
que tais senhores tinham atividades tão diversas quanto o tamanho de sua produção: preocupar-se com as discussões políticas do Império com relação às políticas de mão-de-obra, por exemplo - , com o desenvolvimento do transporte de suas mercadorias através das ferrovias, em franca expansão naqueles tempos, com reuniões junto a possíveis exportadores, com a aquisição de escravos - encomenda, escolha, participação nos leilões com outros senhores - etc. ${ }^{8}$ Assim, a administração da disciplina do trabalho, e dos castigos incontestados e exemplares (Lara, 1988, p. 57-96), era de responsabilidade do feitor, homem de confiança do administrador, que não era escolhido pelo seu grau de crueldade no trato com os escravos, mas por sua competência em desenvolver um código moral de castigos sem que a produção da fazenda fosse estagnada, ainda mais nos dias de ausência do senhor. Portanto, havia uma relação moral, em permanente tensão, é bem verdade, entre o administrador e 0 feitor, e entre 0 feitor e os escravos, entendidos como um grupo de trabalhadores e moradores da fazenda com relações sociais além das de trabalho.

O s escravos das fazendas de café percebiam a chegada de novos escravos, ainda mais quando vinham de outras províncias, identificando modos de falar e de se comportar distintos dos seus, ou seja, a convivência entre aqueles que já estavam nas fazendas e os que estavam chegando nas mesmas era fortemente marcada pela diferença, por um choque de percepções de modos de agir os mais diversos da parte de ambos os tipos de escravos. O s que chegavam sabiam que encontrariam escravos e livres que já se conheciam, com maneiras de se relacionar em construção há algum tempo. Era exatamente no embate entre os diferentes ritmos de vida e formas de sociabilidade entre os escravos que chegavam $e$ aqueles que já estavam trabalhando na fazenda que as regras morais de disciplina e justiça eram testadas. D esse modo, tinha-se o risco de acontecerem inflexões políticas nas relações sociais na fazenda, quando 0 
ritmo das regras morais não acompanhava as modificações da produção e da vida social, fruto das necessidades econômicas que levavam senhores a optarem por comprar escravos de outras províncias.

Nesse artigo, trabalharemos com um assunto pouco abordado pelos pesquisadores da escravidão no Brasil, qual seja, o entendimento das redes de sociabilidade, assim como as formas dos agentes sociais as construírem, seus códigos morais internos às regras de trabalho e da vida na fazenda de um modo mais amplo. Para isso tentaremos recuperar a "fala social dos escravos" presente nos documentos da segunda metade do século XIX, principalmente processos-crime (Chalhoub, 1990; Slenes, 1999), analisando os discursos dos agentes como produtos do seu tempo de vida social (Foucault, 1997). Trataremos também dos silêncios em tais fontes como verdadeiras etnografias (Maggie, 1992, p. 21-36, 39-41) por narrarem os modos sociais de ação e pensamento da sociedade escravista brasileira daquele período, fundamentalmente em dois processos-crime em que escravos são acusados, ou se acusam, de tentarem assassinar, ou terem assassinado, o feitor da fazenda de café na qual trabalhavam. ${ }^{9}$

\section{"Mas o burro disparou." \\ Fazenda Concóndia, Barra Mansa, 1876: escravos, livres e feitor em quais conflitos e união?}

Barra Mansa, província do Rio de Janeiro. Manhã do dia 25 de fevereiro de 1876. Região onde se localizavam várias fazendas de café. Algumas delas tinham trabalhadores escravos, tal como a Concórdia, onde a autoridade do feitor Claudino José Raimundo pesava sobre os escravos. Ao menos, até este dia. Três escravos: Joaquim Pernambuco, natural da mesma província, Paulo e Fortunato, naturais da província do Ceará; e uma atitude: a emboscada para atingir violentamente 0 feitor, logo pela 
Revista de Antropologia, São Paulo, USP, 2003, v. 46 № 1.

manhã, quando este se dirigia a cavalo da fazenda do Retiro para a casa de morada da Concórdia, acompanhado de mais dois escravos, José e Eliseário. Ambos a pé (Arquivo Nacional, Corte de A pelação, processocrime n. 858, caixa 115, galeria $C$, ano 1876). Vamos à cena.

No dia e lugar já assinalados, o feitor Claudino dirigia-se lentamente, montado num burro, em direção à casa de morada da Concórdia. Mesmo percebendo que três escravos estavam de tocaia, esperando-0, continuou seu caminho. Os dois escravos que vinham logo atrás não puderam perceber o perigo do qual se aproximava o feitor. Quando chegaram à altura dos três escravos - que já estavam escondidos em sua tocaia - o escravo Joaquim Pernambuco saltou com uma foice na mão, tentando golpear o feitor Claudino. "Certamente, [Joaquim] teria realizado o seu sinistro intento, se não espantasse o animal, que se afastou a galope do lugar em que se achava."

Joaquim ainda tentou alcançar sua vítima, mas não conseguiu. Enfurecido com esse fato, juntamente com seus aliados - os escravos Paulo e Fortunato - , também armados de enxadas, agrediram mortalmente os escravos acompanhantes do feitor em fuga, que não resistiram aos golpes, morrendo imediatamente. Esta é a versão dos fatos que narramos a partir do depoimento do feitor Claudino, no qual ainda afirmou que os três escravos "ali se achavam escondidos para realizarem o plano que tinham concertado a respeito da [sua] morte".

O feitor já desconfiava do plano? Se pensarmos que sim, não podemos entender o motivo de ter afirmado que as ferramentas dadas por ele mesmo aos escravos, que não deveriam devolvê-las após o trabalho na lavoura - como consta no processo - , tinham se transformado em armas. Além disso, também podemos pensar que o feitor queria testar o nível de insatisfação dos escravos, a partir de sua lógica de homem que tinha a confiança do senhor dos mesmos e dono da fazenda, ou do administrador da mesma, ou de ambos, para disciplinar o trabalho 
dos escravos na lavoura. Não acreditamos que se trate exatamente disso, embora o feitor Claudino nos dê pistas, em seu depoimento, para tal interpretação.

Como Claudino soube de tais fatos, é o que conheceremos agora.

No caminho da casa de morada da fazenda Concórdia, o feitor encontrou com os escravos José Crioulo e Eliseário. 0 primeiro fora buscar uma faca e o segundo, uma enxada - comportamento comum em algumas fazendas. Ambos utilizariam, naquele dia, tais ferramentas em seus trabalhos. Seguiram os três pela estrada. $O$ feitor Claudino não se opôs ao comportamento desses escravos, assim como ao de outros que afirmaram ser uma regra entre eles e o feitor 0 direito de ficarem de posse das ferramentas, e solicitarem outras caso precisassem. Estamos sendo repetitivos. Mas se faz necessário. Eliseário disse que iria cortar capim, por isto a faca.

O feitor Claudino avistou o escravo Joaquim Pernambuco, "que se achava agachado à beira do caminho. Com uma enxada na mão, 0 escravo, assim que avistou o feitor, dirigiu-se-lhe nestes termos: 'espera aí, filho da puta, que tu me pagas hoje'". Em seguida, o burro do ameaçado feitor disparou caminho afora, fazendo seu chapéu cair no chão. Chegando à fazenda, pediu ao escravo Antonio Mulato para buscar seu chapéu. Q uando voltou, contou-lhe o que havia encontrado: dois escravos mortos. $O$ feitor pediu que perguntasse aos outros escravos da fazenda se todos estavam no trabalho, recebendo, mais tarde, a resposta de que eles davam falta não apenas de Joaquim Pernambuco, mas de Paulo e Fortunato. $O$ feitor negro Antonio Mulato afirmou ainda, em seu depoimento, que tinha visto os três fugindo juntos, há pouco tempo.

Agora a versão do feitor Claudino ficou um pouco mais clara. Ao contrário de seu primeiro depoimento, neste segundo - pedido pelo juiz que apurava o caso, para esclarecer vários "detalhes" - identificamos a construção das relações de cumplicidade momentâneas entre 0 feitor e 
outros escravos, incluindo o feitor negro Antonio Mulato - fundamental para a informação da fuga dos três acusados - , na busca dos escravos rebeldes, assim como os motivos para tal "acordo" visando interesse específico. Assim, o feitor Claudino acreditava que tinha castigado Joaquim Pernambuco além do costume, no dia anterior, pois este não queria lhe obedecer, pois, afinal de contas, estava o escravo com as roupas molhadas e não queria trocá-las. Mas desconfiemos dessa informação porque o próprio feitor Claudino afirmou ter ouvido dos outros escravos que Joaquim Pernambuco já havia afirmado que não trabalharia mais para seu senhor.

Então, a motivação do futuro crime teria sido a recusa em trocar as roupas molhadas, em vez da insatisfação anterior de Joaquim?! O feitor afirmou que Joaquim Pernambuco era escravo de "má índole", ao contrário de Paulo e Fortunato, ou seja, apontava-o como um virtual criminoso, o que havia se confirmado com a tentativa de assassinato, pois sua índole era má em relação ao que o feitor Claudino acreditava ser uma boa índole. D esse ângulo, Paulo e Fortunato, de boa índole, quer dizer, de bom convívio com ele, feitor, obedientes às normas do trabalho que ele ditava, teriam sido influenciados por Joaquim Pernambuco. Então, cabe perguntar: 0 que motivou os dois escravos a participar do plano, assim como da ofensiva contra o feitor? Lembremos que, no primeiro e confuso - depoimento, o feitor Claudino disse conhecer um plano de assassinato contra si, tendo como mentor Joaquim Pernambuco, ainda não apontado como um escravo de "máíndole", e tendo como colaboradores os escravos Paulo e Fortunato. Agora, podemos pensar que o feitor já sabia da possível tramóia dos escravos, liderados por Joaquim Pernambuco, de quem já esperava atitude de natureza pessoal. Mas o feitor Claudino não admitiria sua "fragilidade" ante os escravos, o senhor dos mesmos e seu patrão, e do administrador da fazenda, ao ter sido pego de surpresa, ainda mais se levarmos em conta a possível colaboração dos 
escravos Paulo e Fortunato. A possibilidade de não ter tido tempo para escapar, mesmo tendo visto Joaquim Pernambuco à sua espera, é muito grande, pois somente não foi pego graças ao reflexo do burro no qual estava montando.

Voltemos a perguntar: quais teriam sido os possíveis motivos, no entendimento desse jogo de versões, como estamos procedendo, para que os escravos Paulo e Fortunato aderissem ao plano de Joaquim Pernambuco - se acreditarmos na sua existência? "Respondeu [Claudino] que aqueles escravos não gostavam dele, como é muito natural, por ele ser feitor" (grifos nossos). Seguindo esse raciocínio, por que os outros escravos que, "naturalmente", não gostavam dele por ser feitor, não haviam colaborado com o tal plano? E como explicar que a versão apresentada por cinco escravos, ao testemunharem, enfatizou os acusados como exceções na relação com o feitor Claudino, contrariando a versão dos escravos Joaquim Pernambuco, Paulo e Fortunato? Em seu depoimento, o escravo Benedito relatou os fatos seguindo o mesmo roteiro do segundo depoimento do feitor Claudino, assim como o fez 0 administrador da fazenda, Manoel José Machado. Este último, em seu depoimento, afirmou que o escravo Joaquim Pernambuco havia "seduzido" os dois outros escravos para executar o plano, e ainda havia matado os escravos José e Eliseário para que não contassem o acontecido aos demais. Uma vez que o feitor negro Antonio Mulato dissera que os três escravos, Joaquim Pernambuco, Paulo e Fortunato, haviam-se evadido pouco tempo depois do ocorrido, que o próprio feitor Claudino tinha um relacionamento diferente com os três, e que, sabia-se de um plano deles para seu assassinato, seria contraditório acreditar que Joaquim Pernambuco matara os escravos José e Eliseário para que não contassem. Ora, tais informações foram rapidamente disseminadas pelos escravos. 
Revista de Antropologia, São Paulo, USP, 2003, v. 46 № 1.

Lavradores da região, que trabalhavam lado a lado com os escravos no eito, também testemunharam, confirmando a versão que incriminava os três escravos rebeldes. Todos esses trabalhadores, livres e escravos, da fazenda Concórdia, eram feitorizados por Claudino, que agia da seguinte maneira: para os escravos, castigos físicos como punição por desobediências de suas ordens ou por maiores distúrbios durante a execução das tarefas; para os lavradores, homens livres, outras regras na negociação das condições de trabalho. A ssim, no momento em que deveria dar busca dos escravos fugidos, o feitor Claudino recorreu ao lavrador D omingos da Silva Barbosa, que trabalhava junto aos outros lavradores e que, por trabalhar diretamente com os três escravos, seria bom conhecedor de suas formas de agir. No caminho encontraram Francisco Mulato, que lhes disse que, na véspera, o escravo Joaquim Pernambuco falara para os escravos, em plena senzala, que mataria o feitor Claudino. Bem, como o feitor já havia dito que sabia do plano, digamos agora da intenção, de Joaquim Pernambuco para matá-lo, somos levados a acreditar que algum escravo fora lhe dar esta preciosa informação, antes mesmo do raiar do dia - pois a empreitada dos três escravos ocorrera por volta das seis horas da manhã.

É muito vago dizermos apenas que todos os escravos acusaram os três fugitivos do crime, confirmando a versão do feitor Claudino. Vamos nos deter, então, em uma testemunha: Leodório, de 20 anos, natural de Barra Mansa, escravo residente e trabalhador em serviços de roça em Concórdia, fazenda de seu dono, o comendador Torres.

Leodório afirmou em seu depoimento que, no momento do fato em questão, estava levando fubá para a cozinha dos escravos - prestemos atenção nisto que não é um mero detalhe - , quando viu passar o feitor Claudino, num burro em disparada, sem o seu chapéu. Logo, o escravo Leodório estava voltando da casa de morada. Achou tal cena muito estranha, mas continuou andando. Em seguida, deparou-se com dois 
corpos, reconhecendo serem de seus dois companheiros mortos. Entretanto, duas informações em seu depoimento contradizem o dos outros. Mas não o fato social que estamos construindo. ${ }^{10}$

A qui, as querelas que vemos resultam do que aproximou os escravos, lavradores, senhores, feitores e administradores de nós, criando uma narrativa jurídica, a qual procuramos traduzir para a linguagem do antropólogo, ou melhor, do nosso tempo, do nosso interesse, evitando cair em anacronismos (Foucault, 1997). 0 confronto das visões do acontecido, dos crimes, em nosso caso, carrega conflitos e acordos, nos quais priorizamos encontrar seus limites nas ações dos atores históricos, no momento em que tentam manter as regras, até mesmo propondo novas para que isso aconteça, e outros tentam subvertê-las, conforme seus interesses. Ora, os autos dos processos criminais não refletem aquilo que aconteceu, tratando-se de um jogo de percepções estratégicas para a construção de argumentos que levem ao convencimento daquele que detém a autoridade para dizer o que deve ser considerado como verdade jurídica. A questão, para quem julga, reside em decidir qual das versões, somada às investigações policiais, será aceita como a que traz a maior quantidade de elementos que cheguem mais perto da verdade jurídica, a que pode ser provada conforme o jogo das leis, e que estabelece, por fim, o ganhador do jogo de forças que se desenvolve durante o processo jurídico, a partir, também, dos critérios não só institucionais, mas também das experiências de cada um dos envolvidos (Foucault, 1999). Voltemos à análise, a partir de mais depoimentos.

O escravo Leodório afirmou, em seu depoimento, que "havia amizade entre eles [Joaquim, Paulo e Fortunato], que andavam juntos e que 0 acusado Paulo era até companheiro de cama de Joaquim Pernambuco. (...) O s acusados Paulo e Fortunato, já haviam fugido da Fazenda diversas vezes, e, até onde sabia, não havia motivo especial que os levassem a 
praticar a última fuga, visto que nem foram castigados, nem disso estavam ameaçados".

A primeira informação é a de que os três escravos andavam juntos, sendo que Joaquim Pernambuco e Paulo tinham grande intimidade, detalhe que chamou a atenção de Leodório. Fortunato tinha o "costume de fugir", ao contrário de Joaquim Pernambuco, sendo muito difícil sabermos por que não ia junto nessas fugas, em princípio conhecidas por muitas pessoas da fazenda Concórdia. Sabemos, "apenas", ser esse um sinal de uma possível divergência entre os três escravos, que gozavam de uma relação de grande "amizade".

A segunda nos coloca diante de um impasse. É sustentável, na construção da versão do feitor Claudino, que Joaquim Pernambuco foi castigado no dia anterior ao crime, assim como os outros dois escravos, Paulo e Fortunato? Vamos aos depoimentos dos acusados, para depois remontarmos esse quebra-cabeça.

No seu interrogatório, Joaquim Pernambuco, natural da respectiva província, disse que fugiu porque o feitor Claudino tinha lhe batido por duas vezes. Encontrou os escravos Paulo e Fortunato na estrada, e de lá fugiram. Paulo, natural da província do Ceará, disse que não tinha motivos para a fuga. Viu os dois cadáveres e soube das mortes por Joaquim Pernambuco, que teria assumido a autoria dos assassinatos, embora não tivesse a intenção de cometê-los. Fortunato, também natural da província do Ceará, disse que, ao contrário de seu companheiro, fugiu por ter sido castigado pelo feitor Claudino, e que no caminho encontrou com os outros dois escravos. Entretanto, "como de costume", havia combinado a fuga com Paulo.

As fugas de escravos devem ser relativizadas, pois, uma vez que o senhor permitia a ampliação do espaço de circulação do escravo, não podemos afirmar que o fato se caracterize como uma fuga aos olhos do 
senhor. Mas, para outras autoridades ou para outros senhores da região, um escravo fora do olhar senhorial poderia ser, ou quase sempre era, um escravo fugido. São inúmeros os documentos sobre a prisão de escravos que tinham autorização do senhor para sair da fazenda, mas que eram presos por autoridades policiais locais, no século XIX.${ }^{11}$ A pós esse breve registro, voltemos ao processo.

Os escravos Paulo e Fortunato tinham vindo do Ceará, onde o trabalho escravo sofria grande esvaziamento - dentre outros fatores graças às intensas secas que castigavam aquela região do Império, o que levou vários senhores a venderem seus escravos a traficantes ligados ao fortíssimo mercado escravista do Sudeste cafeeiro - até sua abolição na província, em 1884. A fuga era, para muitos escravos, um modo de aliviar o sofrimento de castigos excessivos, aos seus olhos, e mostrar 0 seu protesto, ao deixarem de trabalhar por algum tempo, em prejuízo de seu senhor. Por serem companheiros desde o Ceará - disseram que de lá vieram juntos para a referida fazenda - seria possível que, quando um apresentasse motivos para fugir - é bom lembrarmos de seu costume, afirmado pelo escravo Leodório, e que sempre retornavam para 0 trabalho, sem que fossem punidos por isso - , o outro acompanhasse. O ra, fugindo os dois, menos dois trabalhando, e maior o prejuízo para 0 senhor. ${ }^{12}$ A mesma lógica servia de pauta para a punição de ambos os escravos.

Eles sabiam do motivo que levara o seu parceiro, Joaquim Pernambuco, a tentar assassinar o feitor Claudino? Sim, é bem provável que soubessem, tal como os outros escravos. Joaquim Pernambuco, afirmando não querer matar o feitor Claudino, narrou ter ido encontrá-lo para dizer que, devido aos castigos, suas mãos inchadas impossibilitavam-no de trabalhar. Mas, por que, então, matou os dois escravos que acompanhavam a possível vítima? Afinal de contas, caso sobrevivessem, a sua estória teria uma outra versão, além da do feitor Claudino. Certamente, 
ele contava com a morte deste. O s escravos José e Eliseário vinham atrás, mais lentamente, pois estavam a pé. Joaquim Pernambuco perseguiu 0 burro, mas já era tarde. Quando viu, deu com os dois escravos, José e Eliseário, os quais não poderia ter visto de sua tocaia. Matando-os, contaria a sua versão como se fosse a única. Mas o que os escravos Paulo e Fortunato teriam a ver com isso?

Recordemos que o feitor Claudino afirmou saber de um plano para matá-lo. No entanto, havia dois planos, segundo as testemunhas e os acusados. Primeiro, o plano elaborado pelo escravo - de "má índole" Joaquim Pernambuco de matá-lo só. Segundo, o dos escravos Paulo e Fortunato fugirem apenas os dois. No entanto, ao fugirem, seriam vistos como os autores do crime: Joaquim Pernambuco, o assassino, e Paulo e Fortunato, em conformidade com a atitude do companheiro vindo no mesmo período para a fazenda, também de uma província do Norte, Pernambuco.

A alegação de andarem juntos é um indício de terem um laço de união maior do que com os escravos há mais tempo na fazenda, para resistirem ao novo campo de relações sociais com pessoas suas desconhecidas, mas conhecidas entre si há algum tempo. O s três escravos não faziam parte do acordo entre os escravos mais antigos e 0 feitor, quanto às regras para a disciplina do trabalho e da vida em geral na fazenda Concórdia, tal como a punição experimentada na "pedagogia da violência" (Machado, 1987, p. 87-98) aplicada pelo feitor da mesma, percebida como injusta por Joaquim, Paulo e Fortunato. Esse seria, então, mais um ponto a partir do qual os três escravos teriam se unido, ao identificarem a mesma idéia e 0 mesmo sentimento perante as injustificadas, aos seus olhos, atitudes ditas punitivas aplicadas pelo feitor Claudino a eles. Assim, o feitor Claudino não teria criado com eles o mesmo vínculo que criara com os demais escravos, e mesmo estes não aceitariam muito fácil a chegada de novos companheiros, o que era muito comum 
nas fazendas do Sudeste, depois de 1850, quando do final do tráfico internacional e da intensificação do tráfico interno. Ora, cada um dos grupos, ou gangs, de escravos de uma mesma fazenda estabelecia suas regras para escolha dos seus membros, visando dar conta das tarefas do dia para que, teoricamente, ao terminarem mais rapidamente as mesmas tratassem de questões pessoais no tempo restante.

Fato a ser considerado são as diferentes rotas de tráfico negreiro que alimentavam as províncias do Sul e do Norte, o que determinava diferenças culturais, "heranças" simbólicas africanas diferentes, e até pouco conciliáveis. 0 trabalho nas fazendas de café era muito diferente do trabalho com os produtos cultivados no Norte, o que dificultava ainda mais a aceitação dos escravos vindos desta região pelos já estabelecidos nas fazendas do Sudeste. As dificuldades não eram empecilho, mas sim anteparos sociais a serem transpostos para o caso de os escravos novos na fazenda - não necessariamente os vindos do Norte, mas herdados de um parente do senhor, ou recebidos como pagamento de alguma dívida, ou até mesmo comprados de senhores das próprias províncias do Sul se adaptarem aos serviços de gangs, que passaram cada vez mais à rotina do trabalho das fazendas de café em sua época de expansão, nas regras internas de construção de famílias ou pequenas economias através das mesmas etc. (Machado, 1994, p. 21-66; Slenes, 1999, p. 188-89).

D essa forma, acreditamos que tanto os escravos que depuseram, todos nascidos na região, portanto há mais tempo adaptados ao trabalho na Concórdia, quanto os lavradores que trabalhavam com esses escravos acostumados com as configurações dos problemas de convívio na fazenda, quanto o feitor negro Antonio Mulato, e o feitor Claudino que aparentemente havia construído com estes atores históricos acordos silenciosos de trabalho e convivência, não tolerariam a quebra dos modos de construção das relações sociais ali estabelecidas pelos novos escravos. Estes últimos pareciam ter encontrado seu ponto de colisão na não acei- 
Revista de Antropologia, São Paulo, USP, 2003, v. 46 № 1.

tação das regras de punição, da lógica dos castigos normativos aplicados pelo feitor, assim como no cuidado que o mesmo quis ter com Joaquim Pernambuco ao mandar que trocasse suas roupas molhadas evitando, possivelmente, alguma reação do escravo que pudesse trazer-lhe problemas com seu patrão, e senhor do escravo. Para quem chegava às fazendas, a construção das regras de convivência era uma necessidade, e, a partir do momento em que não conseguia lidar com as barreiras de relacionamento com as pessoas da fazenda, tais como a coesão entre os trabalhadores - escravos e/ ou livres - , lançava mão das formas simbólicas de comunicação que conhecia para manifestar sua opinião, seu posicionamento quanto às situações de trabalho, e de vida em geral, nas quais se via forçado, ao menos momentaneamente, a tentar se inserir.

Voltemos aos castigos do feitor Claudino a Joaquim Pernambuco. Não sabemos qual foi o motivo, mas esse escravo deveria ter fortes razões para não querer tirar as roupas molhadas e trocá-las por outras que estivessem secas. Mesmo com a ordem do feitor, Joaquim se recusou a trocá-las e foi castigado. A chou injusto, pois não era a primeira vez que fora, tal como o escravo Fortunato, castigado com mais violência do que os seus colegas mais antigos na fazenda, ao menos segundo seus parâmetros de comparação. Talvez o feitor Claudino quisesse enquadrálo o mais rápido possível nas normas e ritmos de trabalho da fazenda, acelerando o processo de adaptação do escravo à vida social na Concórdia. A morte do feitor significaria a quebra dos acordos silenciosos, construídos ao longo do tempo, entre os escravos e os trabalhadores livres da fazenda Concórdia? Podemos acreditar que sim. Com a vinda de um novo feitor, todos os trabalhadores da fazenda estariam num mesmo patamar de relações de trabalho, obrigados a construir novos "acordos" com um novo feitor, a partir da estaca zero. 0 escravo Leodório afirmou que Joaquim Pernambuco não havia sido castigado na véspera, embora o feitor Claudino a isso tenha atribuído o motivo 
da tentativa de assassinato de que fora vítima. Algum erro na troca de informações entre os escravos fez com que ele não apresentasse a mesma versão dos fatos, fornecendo-nos o indício para a compreensão de todo o processo criminal como fato social, com relação à construção destes acordos silenciosos nas relações entre escravos, feitores, administradores e demais trabalhadores livres.

A ssim, confirmamos nossa hipótese. Os escravos e trabalhadores livres de Concórdia, junto com os dois feitores, concordavam quanto à continuação dos acordos construídos, pelos quais todos saíam ganhando, mantendo a "paz" que senhores e moradores dos núcleos urbanos próximos tanto reclamavam faltar em regiões onde a concentração de escravos aumentava a cada ano. É o que se podia ler, por exemplo, no jornal Monitor Paulista, de Bananal, província de São Paulo, em notícia de primeira página do número de 3 de março de 1878, que dizia que "a freqüente reprodução de atentados cometidos por escravos contra a pessoa de seus superiores tem por mais de uma vez preocupado o espírito público, e hoje, em conseqüência de recentes e lutuosos acontecimentos, em fazendas da região, está prendendo a atenção de quase toda a imprensa paulista; 0 assunto é gravíssimo!" (Biblioteca Nacional, Seção de Obras Raras, documento microfilmado).

Mas, o que fazer com os três escravos acusados, Joaquim Pernambuco, Paulo e Fortunato, uma vez que estavam vivos e, se absolvidos, voltariam à fazenda e tornariam a ameaçar a tão funcional "paz" ? O senhor, que deveria fazer a defesa dos escravos, que eram parte de seu patrimônio, assim como arcar com as despesas do processo, e não fazia parte do acordo acima afirmado, agiria de que maneira? Pagou um advogado e um curador para a defesa dos acusados, como vários senhores faziam; não os abandonou à justiça, outra opção de muitos senhores quando se encontravam em situação parecida; muito menos os libertou, para evitar prejuízos ainda maiores, como as custas do próprio processo criminal, caso 
Revista de Antropologia, São Paulo, USP, 2003, v. 46 № 1.

este se alongasse demais, em detrimento de seus interesses. O s três escravos tinham ainda muito tempo de atividade e força para 0 trabalho, fato que compensava as despesas: todos tinham aproximadamente 25 anos. Assim, para a defesa, os argumentos eram dois: que os fatos alegados não caracterizavam tentativa de homicídio, e que os autos do processo não forneceram dados suficientes para que esta hipótese fosse considerada - ou seja, lutavam claramente dentro da lógica da construção de uma verdade jurídica, seguindo as regras institucionais da construção do inquérito e do processo, como nos referimos anteriormente. É bom frisarmos que a defesa não afirmou que a hipótese fosse socialmente mentirosa, ou inverossímil, pois não era isso que estava em jogo, mas sim o fato de ser insustentável a partir dos dados fornecidos à justiça.

D essa maneira, podemos dizer que temos um julgamento envolvendo, como pano de fundo, os agentes do acordo silencioso contra o senhor. Os primeiros querendo se livrar dos três escravos, e o segundo, querendo seus trabalhadores prontos para retomar o serviço da roça. Não sabia das relações sociais complexas, da cultura do trabalho, dos valores éticos construídos em sua própria fazenda, na densidade que foram tomando ao longo do processo. Voltando alguns parágrafos, a informação sobre os escravos terem sua cozinha comunitária na fazenda é um relato da conquista que haviam conseguido, representando a autonomia na feitura da comida e, esta sim, de conhecimento do senhor, posto que era uma parte da casa de morada que era por eles utilizada. ${ }^{13}$

A interpretação do juiz levou-o ao veredicto de que o escravo Joaquim Pernambuco era culpado por tentativa de homicídio e duplo assassinato, sendo condenado a galés - leia-se trabalhos forçados para o Estado - perpétuas. Quanto aos outros dois escravos, Paulo e Fortunato, 0 juiz entendeu terem auxiliado na execução do plano criminoso e de terem compartilhado da intenção de assassinar o feitor, sendo condenados a cem açoites e a trazerem por seis meses ferro ao pescoço - assim 
seriam exemplo para os demais, e não estariam totalmente impossibilitados ao trabalho. Mas a punição refletiria, para os outros escravos da fazenda, uma forma de humilhação dos condenados, e também um exemplo espetacular para que os acordos fossem mantidos, valendo a pena serem renovados diariamente.

0 senhor apelou da sentença, ${ }^{14}$ mas as condenações foram mantidas. Entretanto, nosso estudo não acaba por aí. Ao tomar essa atitude, 0 comendador Antonio Lourenço Torres possibilitou a participação de um novo ator nesse processo: 0 promotor público, José Álvares Rubião Júnior. Sua argumentação contra a revisão da sentença colocou por terra os possíveis argumentos de sua amenização, e revelou seu universo ideológico acerca da disciplina da escravidão, da propriedade privada e da defesa da ordem senhorial.

Primeiramente, abriu seu parecer confirmando a versão dos trabalhadores da Concórdia, exatamente como abrimos esta parte do artigo. Para ele, o castigo que o feitor Claudino aplicou ao escravo Joaquim Pernambuco, na véspera do atentado, não deixava dúvidas quanto à natural reação do escravo, aflorando-lhe o sentimento de vingança. Justificou, pois "todas as fases porque passa 0 crime, desde 0 seu pensamento, ato interno e psicológico, até a sua execução, fato material e punível, foram praticadas. (...) A execução (...) não se concluiu independente da vontade do agente criminoso". Por conseguinte, "passou, portanto, o crime por todas as suas vicissitudes, até à sua manifestação punível como tentativa".

Entretanto, a desobediência escrava poderia significar um grande desequilíbrio nas relações de poder, a partir da visão senhorial. Vejamos o seguinte exemplo. Nova Friburgo, 12 de junho de 1867. 0 chefe de polícia interino, João da Costa Lima e Castro, suspeitando que os escravos Modesto e Filipe estivessem indo em direção às fazendas Campestre e São Fidélis, ordenou que o delegado "prendesse os criminosos, sem 
perda de tempo" (Arquivo Público do Estado do Rio de Janeiro, PP, coleção 5). Suspeitando que Modesto e Filipe tivessem se evadido das tais fazendas, ordenou ainda que o delegado de Cantagalo desse busca na fazenda Subaio. D essa forma, fecharia o cerco aos escravos acusados de liderar uma insurreição de grandes proporções, em 6 de junho, na fazenda herdada por Joaquim Pires D omingues. D epois de ferirem este último com um tiro de espingarda, vários escravos fugiram, e dizia-se que voltariam para continuar exercendo seu domínio na fazenda do seu falecido pai, sem considerar a legitimidade moral da mudança de senhor. A "paz" nas fazendas da região estava ameaçada até a captura e prisão dos insubordinados escravos. Voltemos ao nosso caso.

O promotor público, assim como o juiz, estava distante das querelas entre os trabalhadores, escravos e/ ou livres, da fazenda Concórdia, e dos conseqüentes interesses que tinham nos rumos do processo, e, uma vez acontecida, da apelação. Sua perspectiva da disciplina era bem clara: "quem conhece a disciplina de nossos estabelecimentos agrícolas, o respeito, que têm os escravos para com os representantes da autoridade de seus senhores, a imensa força moral que sobre eles pesa, há de necessariamente reconhecer que bem procedeu 0 juiz, classificando 0 ato do réu em tentativa de morte".

É bem provável que um promotor de justiça, julgando um caso de crime cometido por escravos, na década de 1870, em fazendas de café, não tivesse receios quanto ao possível alastramento para fazendas vizinhas deste acontecimento desafiador da ordem social da elite senhorial. 0 clima entre alguns senhores de escravos, autoridades policiais e membros do poder judiciário não era dos mais tranqüilos com relação às "ondas negras" ${ }^{15}$ Fosse pelo medo paranóico, fosse pelo medo "socialmente real", havia uma instabilidade emocional gerada pelos perigos que a agitação dos escravos pudesse levar, em seu modo mais amplo, aos "bran$\cos ^{\prime \prime}$, mais precisamente, aos senhores e seus prepostos. Foi nessa 
ambiência que, em 18 de dezembro de 1872, o ministro da G uerra, João José de O liveira Junqueira, recebeu uma carta do presidente da província de São Paulo, Manoel Antonio D uarte de Azevedo, na qual este afirmava que "por parte dos escravos começa a manifestar-se tendências de movimento insurrecional" (Arquivo Nacional, IJ6-20, 1872-75). Assim, pedia, "por ser insuficiente a força ali existente para manter a ordem pública em uma dessas emergências", que fosse "reforçado o contingente de primeira linha [ali] estacionado". No entanto, o parecer do promotor não continha medo, ao menos nas linhas escritas, mas sim nas entrelinhas do que afirmava. A ordem, segundo afirmou, existia, era bem conhecida, sendo anormal a sua quebra, portanto, os três escravos, Joaquim Pernambuco, Paulo e Fortunato eram exceções à regra das relações de trabalho pensadas como universais entre senhores e escravos.

As palavras do promotor zelavam pela ordem dessas relações unicamente vistas como jurídicas, ou seja, senhor e seus prepostos versus escravos, e não em seus vários matizes sociais. 0 juiz, que deveria representar a manutenção da ordem, nome ligado ao funcionamento da burocracia do Estado imperial, tomou a atitude certa, conforme 0 entendimento de quem o havia ali colocado para arbitrar nesse tipo de questão.

A nalisando as informações que pesavam sobre os criminosos, o promotor acreditava conseguir controlar, em alguma medida, as perigosas e audaciosas atitudes dos escravos, que seriam um atentado à propriedade privada, dando prejuízos enormes aos senhores. 0 plano dos três acusados e a sua execução seriam um golpe de mestre contra os interesses do senhor, aliás, de qualquer senhor que enfrentasse tal forma de protesto político de escravos. 0 senhor perderia os escravos, desde o momento em que o crime fosse cometido, considerando "a natureza especial do processo de escravos, em que são os senhores ordinariamente prejudicados, não só com a perda dos serviços, de quantias para custos e até do próprio escravo". 
Revista de Antropologia, São Paulo, USP, 2003, v. 46 № 1.

0 promotor conseguiu manter a versão dos trabalhadores da fazenda Concórdia, agregando mais uma idéia. Afirmou que Joaquim quis matar o feitor Claudino, pois caso o deixasse vivo, apenas atacando-o, seria castigado tão duramente quanto na noite anterior ao crime. Os três escravos, insatisfeitos com os critérios de justiça do feitor Claudino, só teriam essa chance para escapar das punições que recebiam e das humilhações diante de seus companheiros de senzala; assim, somente ajudando-se mutuamente chegariam a alguma forma de quebrar com uma regra da vida na fazenda Concórdia que lhes era moralmente indevida. E ra o reflexo da não aceitação e da difícil adaptação que estavam passando, há mais ou menos dois meses, desde a vinda de Joaquim Pernambuco da província homônima, e de Paulo e Fortunato, do Ceará. Ao afirmar isso, indiretamente o promotor reconhece que há uma cisão nas relações dos três acusados com, ao menos, o feitor Claudino, diferentemente dos outros trabalhadores da mesma fazenda. Agora podemos compreender por que, no seu entendimento, "dos autos está provado que, castigado o escravo Joaquim Pernambuco, concertou ele com Paulo e Fortunato, seus companheiros de leito e íntimos parceiros, o plano da vingança; que fugiram juntos, que juntos estavam no lugar da ação, e que dali tomaram a mesma direção, sendo presos conjuntamente".

No final de seu parecer, que confirmou a sentença do juiz, o promotor voltou a insistir no argumento com relação à lógica de causa e conseqüência da atitude dita criminosa dos escravos, ao afirmar que o crime seria uma natural reação dos escravos ao primeiro fato, qual fosse, a severa punição que haviam sofrido. A "paz" em Concórdia havia voltado. Os interesses dos atores sociais foram percebidos de maneiras diferentes entre eles mesmos, numa mesma situação, dentro de um mesmo caso. 0 promotor defendeu, como mostramos, a propriedade como um direito do senhor, jamais podendo ser prejudicado em processos criminais de escravos. Ao longo do seu parecer, suas certezas foram contra os 
interesses do senhor e a favor dos trabalhadores da fazenda Concórdia, onde os escravos ali estabelecidos há algum tempo tinham grande peso na manutenção do acordo silencioso por ele não levado em conta com tamanha dimensão. 0 que parece ser uma contradição, toma outro rumo quando da investigação da estrutura de poder e das alianças envolvidas em cada caso de "insurreição" escrava, em cada fato social historicizado. O s escravos e demais trabalhadores agradeceram a colaboração de um membro da elite imperial, que pôde "ajudá-los" nessa causa, e mesmo os senhores da região, quando do medo da expansão dessa revolta para as suas fazendas.

\section{A cartilha do administrador e a reza do feitor: os limites morais e a "pedagogia da violência" para os escravos da fazenda de José Carneiro Bastos, Mogi-Mirim, 1872}

José Fernandes Guimarães chegou à fazenda de José Carneiro Bastos, em Mogi-Mirim, com sua esposa, Maria Antonia do Carmo, na noite de 30 de setembro de 1872 (Arquivo Nacional, Corte de Apelação, processo-crime n. 591, maço 148, galeria $C$, ano 1873). Fora contratado para feitorizar os escravos que trabalhavam na referida fazenda de café. Em seu primeiro dia de serviço, exatamente no dia seguinte ao de sua chegada, foi assassinado por alguns dos escravos que trabalhavam na plantação de arroz da fazenda e eram supervisionados por ele. 0 principal acusado do crime foi João Maranhão.

D essa vez faremos diferente. O uviremos primeiro ao acusado, para depois confrontarmos sua versão - caso haja confronto - com outras versões do crime.

João Batista. Este é o nome do escravo conhecido como João Maranhão, natural da província que lhe dá nome, com 19 anos, na fazenda 
Revista de Antropologia, São Paulo, USP, 2003, v. 46 № 1.

há apenas dois meses. Em seu depoimento, admitiu ter matado o feitor, quando ele e os outros escravos trabalhavam na plantação de arroz. 0 feitor achava que estavam cavando as covas para a plantação de maneira irregular, tecnicamente incorreta. Na ocasião, João Maranhão retirou-se para 0 mato, a fim de fazer necessidades fisiológicas - afinal de contas, sempre procedera assim, sem pedir permissão a alguém, quando a vontade vinha. Quando voltou, o feitor ainda repreendia seus parceiros, quando tentou castigá-lo com um relho:

Então ele [João Maranhão], munido da enxada, com que estava, armou a esta e neste ato os seus parceiros fizeram o mesmo e descarregaram em ato contínuo as enxadas sobre o dito feitor, que caiu por terra, não podendo ele precisar os nomes dos seus parceiros que concorreram para 0 assassinato.

O escravo João Maranhão e seus companheiros estavam ao redor do feitor José Fernandes, e apenas os escravos "pequenos", isto é, as crianças - que eram encarregadas das covas menores, por suas mãos serem mais apropriadas a isso - não golpearam o feitor que, mesmo caído, continuou a sofrer com a fúria do grupo. No depoimento, João Maranhão defendeu-se quanto a sua participação no crime, dizendo que somente deu uma pancada, a primeira de todas, quando o feitor José Fernandes ainda estava em pé, acreditando, ainda, ter sido um golpe mortal, por ter acertado na cabeça, logo atrás da orelha esquerda, provocando grande sangramento. Q ueria que assim o fosse, pois, segundo afirmou, desejava matar o feitor José Fernandes. Por que este haveria de castigar João Maranhão, quando foi ao mato, numa situação aparentemente tão natural na vida daquela fazenda? Provavelmente, havia um código de autoridade que o feitor José Fernandes queria, em curtíssimo prazo, impor aos escravos, pois, depois de satisfazer a necessidade corpórea, João Maranhão, "quando voltou, passou perto do feitor com 
o chapéu na cabeça como era de costume, que este não gostando quis castigá-lo" (grifo nosso).

O escravo deveria cumprimentar o feitor quando retornasse ao trabalho, numa espécie de pedido de licença a quem era a autoridade naquela ocasião, e que acreditava ser isto realmente necessário para a manutenção das relações de poder com os escravos. Porém, o feitor José Fernandes não acreditava que a autoridade do papel social que exercia com vistas à obediência dos escravos devesse ser construída nas relações cotidianas, formatadas no diapasão das redes de sociabilidade e dos códigos morais quejá corriam na fazenda, enão apenas por ele ser feitor/ livre/ empregado do senhor versus escravos/ trabalhadores/ propriedade do senhor.

Continuando seu depoimento, João Maranhão afirmou que deu duas pancadas, e não apenas uma, como havia declarado anteriormente, sendo a segunda desferida quando viu que o feitor havia se levantado, ainda estando vivo. Como não havia morrido com a segunda pancada, seu parceiro João Baiano também o golpeou, seguido por Martinho. Todos os escravos utilizaram suas enxadas para golpear o feitor. Ao examinar 0 corpo do mesmo, o escravo Pedro verificou que não estava morto, constatação que levou todos os escravos a ficarem com receio, achando que era melhor verificar se não havia "oração" no corpo da vítima, atribuindo a tal fato o motivo da sua demorada e lenta morte, depois de tanto apanhar. O s escravos não conheciam o feitor José Fernandes, por ser seu primeiro dia de trabalho; pela manhã o administrador da fazenda, Torquato, deu-lhe um cacete de peroba, e apresentou-o com as seguintes recomendações - ditas em alto e bom som, perante todos os escravos:

(...) que castigasse os escravos com relho, com o cacete se fosse preciso, que os amarrasse para serem castigados na escada com bacalhau e trazer-lhes fora as carnes das nádegas, para delas fazerem bifes e do sangue chouriço. 
Logo em seu primeiro problema com os escravos, o feitor não fez por outra: castigou dois deles severamente, pouco depois de ser apresentado aos trabalhadores. No serviço da roça, continuava ameaçando os demais e, conseqüentemente, obliterando, logo no começo da jornada, os trabalhos a serem feitos, provocando contraproducente clima de tensão junto aos escravos.

Em seu depoimento, o escravo João Baiano - mais um das províncias do Norte - com 26 anos, natural da Bahia - e que, de tão pouco tempo que chegou à fazenda, tinha dúvidas se seu senhor era José Carneiro Bastos ou Camilo de Andrade - , confirmou a severidade com que agiu o feitor José Fernandes, desde o momento de sua chegada, ao levar ao pé da letra a cartilha que 0 administrador Torquato rezava. João Baiano relatou, ainda com mais vagar do que seu parceiro João Maranhão, o episódio do castigo aos dois outros escravos, Manoel e Martinho. Afirmou:

(...) que então ele [João Baiano] dirigia-se ao serviço de um açude onde logo o feitor mandou deitar o seu parceiro Manoel, para surrar, declarando que não surrava negro de pé, e logo depois fez o mesmo com o seu parceiro Martinho.

João Baiano repetiu a história sobre a ida de João Maranhão ao mato, assim como a do problema com o feitor José Fernandes, quando de seu retorno. Voltemos à pergunta já feita anteriormente, e que gostaríamos de responder por outro caminho: por que o feitor José Fernandes haveria de castigar João Maranhão, quando foi ao mato fazer necessidades fisiológicas, numa situação que parecia tão natural para os escravos? Segundo João Baiano, quando João Maranhão "passou pelo feitor com o chapéu na cabeça quase tapando os olhos, José Fernandes disse que não gostava e não consentia que negro estivesse com o chapéu daquele modo". 
Confirmamos, dessa forma, nossa resposta. Parece que aqueles escravos entraram em acordo, acabados de chegar de províncias do Norte para trabalhar na fazenda de café, quando foram apresentados ao novo feitor, José Fernandes. Na sua frente, o administrador Torquato deu "carta branca" para agir com violência, segundo a necessidade de se manter a disciplina do trabalho. As relações entre ele, feitor e os escravos nem mesmo havia começado para que pudesse saber como deveria agir num grupo tão novo naquela fazenda, ou seja, não aplicou as normas segundo um padrão específico de ritmos de trabalho e punição, mas sim segundo recomendações anteriores à sua relação com os trabalhadores. Entendemos, assim, que a negociação entre o feitor José Fernandes e os escravos era impossivel de se dar, inexistindo um canal de comunicação com 0 administrador e o senhor que não fosse pela morte dos feitores que não agissem dentro de regras morais de punição na ótica dos escravos. Seguindo tal raciocínio, podemos reconhecer que 0 administrador também não era dado ao contato social mais político com os escravos, tal como vimos no primeiro estudo de caso. Mal conhecia os escravos, que, vindos de províncias do Norte, também mal se conheciam. No entanto, os escravos possuíam uma percepção de que deveriam garantir limites nas relações com o feitor, uma vez que o administrador queria obstruir qualquer possibilidade de negociação mais direta da vida na fazenda. Assim, tomaram a mesma atitude de protesto para encerrar as chances do feitor José Fernandes trabalhar na fazenda, agredindo-lhes conforme uma relação moral por eles não reconhecida, assim considerada ilegítima. Agiram numa situação localizada, a partir de um acúmulo de frustrações morais que se construiu desde 0 primeiro contato que tiveram com aquele feitor, pela via dos castigos que, fora de uma lógica disciplinar, não poderiam ser reconhecidos como tais, mas sim como uma "mera e injustificada violência", e, por isso mesmo, inaceitável. 
Revista de Antropologia, São Paulo, USP, 2003, v. 46 № 1.

Todos os escravos que depuseram afirmaram não terem feito acordo algum para o cometimento do crime - ao contrário do que vimos na fazenda Concórdia. Aqui, o caso seria o inverso. Escravos recém-chegados das províncias do Norte formaram, minimamente, relações de confiança que permitiram o protesto coletivo contra a imposição de regras de trabalho que nem sequer estavam postas anteriormente - não para aqueles trabalhadores, daquela fazenda. Caso fossem uma minoria, compreenderíamos que os escravos migrados pelo tráfico interprovincial estariam lutando, tal como em Concórdia, pela localização, afirmação e construção de estatutos morais silenciosos, mas fortemente presentes e conhecidos, das regras da vida social na fazenda, fundamentalmente nas relações de trabalho. Todos os escravos eliminaram automaticamente a figura do injusto feitor, tirando a possibilidade de novos conflitos. 0 recado estava dado ao administrador, que deveria rever seus métodos de disciplina para que novos conflitos com aqueles escravos não se tornassem constantes, e para que os lucros do senhor com a produção econômica da fazenda, assim como seu investimento na aquisição de novos escravos, não fossem prejudicados. ${ }^{16}$

Mas, a reunião dos escravos, se não houve com relação ao planejamento do crime - que, ao que parece, não fora planejado - , houve quando adotaram a proposta de João Maranhão, para reunirem os demais e irem à delegacia de Campinas. Lá contariam juntos o ocorrido, sendo muito difícil que todos fossem presos, pois isso acarretaria um prejuízo imediato ao senhor, que possivelmente reclamaria com veemência se tal fato ocorresse. Os escravos concordavam com a morte do feitor José Fernandes, contestando a falta de motivos pelos maus tratos que ele em pouquíssimo tempo havia lhes infligido. Eis a origem desse processo criminal, acontecido a partir dessa atitude política dos escravos, em sua maioria vindos de províncias do Norte, numa demonstração de reivindicação das regras que norteavam as condições de trabalho, recla- 
mando justiça numa ação de caráter coletivo, uma vez que todos mataram - ao menos na versão que aceitaram assumir perante a justiça para jogar o jogo das verdades jurídicas - o feitor José Fernandes, talvez acreditando que dificilmente seriam punidos pelas autoridades policiais caso se apresentassem em conjunto à delegacia mais próxima para notificar e assumir o crime.

D a mesma maneira, em concomitância com essa sensibilidade para a política da fazenda, mesmo com pouco tempo de chegada, os escravos estavam forjando um novo conjunto de regras nas relações com o administrador, e dando os parâmetros para que ele repensasse como deveria instruir o trabalho do futuro feitor. Pelo tempo que disseram de sua chegada à fazenda, é possível que os escravos vindos do Norte tenham sido vendidos através do mesmo traficante, da mesma casa de comissão, e começado a construir as alianças políticas neste percurso. ${ }^{17}$

Houve outra proposta? Sim, a dos escravos João Baiano e Martinho, para que fossem à casa do administrador Torquato e contassem o ocorrido. No entanto, quando ouviram a proposta de João Maranhão, segundo seus depoimentos, concordaram que indo à delegacia, iriam se defender dos castigos do administrador, pressionariam-no a mudar as lógicas de punição e castigo da fazenda, pois com a instauração do processo-crime seu senhor tomaria conhecimento dos fatos, ouvindo os escravos. Além do mais, não seriam condenados automaticamente, no máximo presos por pouco tempo, pois seu senhor, provavelmente, faria de tudo para os soltá-los em virtude do prejuízo que teria não só na fazenda, mas com os custos de cada etapa do processo jurídico. Para que isso desse certo, os escravos deveriam dizer que todos eles, inclusive as crianças, foram os autores dos golpes que resultaram na morte do feitor José Fernandes. Mesmo não sendo todos assassinos, os quatro escravos que golpearam o feitor representariam a vontade do grupo de um total de 16 escravos. 
Há, ainda, outro fator agravante para os escravos terem tomado essa atitude. Os "pequenos" seriam em breve castigados pelo feitor, por não estarem cavando para o arroz segundo sua vontade, segundo seu critério técnico. Isso ocorria, pelas afirmações do único escravo do grupo nascido na província do Rio de Janeiro, Pedro Pequeno, de 16 anos, enquanto João Maranhão estava no mato. Q uando se preparava para castigar os "pequenos", o feitor parou um momento a fim de punir João Maranhão. Esse motivo dos possíveis castigos às crianças seria um dos argumentos para que os outros escravos, e não apenas João Maranhão, que não teve conhecimento do fato, tivessem golpeado o feitor durante tanto tempo, uma vez que ele estava no chão, e que a agressão já havia começado. No momento da ameaça às crianças, prováveis filhos de escravos do mesmo grupo, o limite do suportável havia se rompido, não faltando mais nada para eliminarem aquele representante da possível inflexão política das relações sociais naquela fazenda. 0 feitor José Fernandes também atingiria uma parte preciosa do investimento senhorial, pois as crianças eram as garantias de mão-de-obra para um futuro cada vez mais incerto para um senhor de escravos no Brasil daqueles anos. 0 escravo Pedro Pequeno também era novo na fazenda, estava lá havia apenas dois meses, e, tal como os outros escravos que depuseram, não sabia o nome de vários companheiros do grupo. A té mesmo o escravo Pompeu, natural da Bahia, também há apenas dois meses na fazenda, mais habilidoso que os demais, especializado em seu serviço de alfaiate, portanto mais caro e de alto investimento do senhor, concordou com a atitude dos outros quatro companheiros. A natureza do cotidiano da vida de Pompeu na fazenda em relação oposta a de seus parceiros, pois não ficava todo o tempo trabalhando na roça, aponta um importante sinal de apoio e, mais do que isso, confiança no sucesso do plano. 
No final, João Baiano e João Maranhão foram condenados a 200 açoites e ferro ao pescoço por cinco anos, sendo todos os demais absolvidos, isto é, o plano deu certo, para os escravos, e, por conseguinte, para o senhor.

\section{Conclusão: conjuntura social da escravidão e construção da emancipação}

Vimos, nos casos analisados, que os escravos acusados como autores dos crimes foram os recém-chegados de províncias do Norte, um sintoma do processo de inflexão política das relações sociais que sofriam nas fazendas do Sudeste. Seus critérios morais de convívio social, mais precisamente com pessoas próximas, eram forjados diariamente, quando se posicionavam ante a gramática das relações sociais do grupo de escravos já estabelecidos na fazenda, no cerne da dinâmica das redes de sociabilidades das quais tomaram parte e, mesmo, das relações de ruptura existentes na mesma. ${ }^{18}$ Assim, os escravos migrados encontraram acordos invisíveis entre as pessoas na fazenda, devendo localizá-los para se tornar cada vez menos estrangeiros, para construírem seus próprios acordos silenciosos. Isso não anula as relações de conflito existentes em qualquer grupo social. Nem mesmo podemos pensar na inevitável vontade de interagir e criar sociabilidades pacíficas dos escravos estrangeiros à vida na fazenda, muito menos dos já estabelecidos na mesma.

As versões dos crimes são similares, tanto nos depoimentos dos escravos, quanto nos dos feitores, administradores e trabalhadores livres. Percebemos incongruências na lógica factual das versões, ao pensarmos a construção das sociabilidades e as concordâncias aparentes, tendo como pano de fundo rupturas das regras de convívio - por exemplo, escravos jovens concorrendo com os mais velhos por mulheres escravas, costu- 
mes de trabalho, diferentes concepções de religiosidade, choques de idéias de justiça e moral nas relações de trabalho. Enfim, os que não se adaptavam deveriam ser expulsos, excluídos pelos próprios membros da rede social da fazenda, daquele lugar. O u mesmo, inversamente, tentar obliterar, brecar a dinâmica das relações com o feitor que vissem como indevidas, injustas, inaceitáveis, em atitudes mais ousadas de eliminação do feitor, como vimos no caso da fazenda Concórdia. Mas, caso um novo feitor ou administrador não fosse reconhecido como uma autoridade no exercício de seu papel, os escravos eliminariam a figura negativa representada por este, até mesmo para os fins econômicos do senhor. Como vimos em nosso segundo estudo de caso, a violência não se basta, não é uma teia que se tece a si mesma, é uma relação de poder, ou seja, somente pode ser entendida como e enquanto uma relação social, legitimada ou contestada de várias formas, circunscrita em suas características históricas (Foucault, 1999).

Identificamos, então, a existência de um choque entre a justiça do Estado e ajustiça das lógicas pela qual as pessoas orientavam a experiência de vida na fazenda. A primeira, cada vez mais atenta aos problemas das formas de controle dos senhores sobre a mão-de-obra, ${ }^{19}$ julgando os criminosos de maneira a voltarem para o convívio na fazenda; a segunda, montando versões que incriminavam em grau tão grande os escravos, feitores e administradores que ofendessem suas regras, que ficaria difícil não serem condenados ao menos a vários anos de reclusão, senão a galés perpétuas, demitidos, ou mesmo assassinados. ${ }^{20} \mathrm{~A}$ sensibilidade senhorial se fazia múltipla, a partir da forma como o senhor atuava com 0 intuito de resolver o problema que, naquele momento, causava grande agitação entre os trabalhadores, escravos e demais homens livres de suas fazendas. No primeiro caso por nós analisado, vimos a decisão do senhor de levar o processo até o fim, possivelmente calculando os vantajosos efeitos que o exemplo punitivo dos três escravos provocaria na 
continuação da "paz" em sua fazenda Concórdia; já no segundo caso, vimos como um grupo de escravos recém-formado, em sua maioria vindos do Norte, agiu para poder fazer valer as regras morais de trabalho e vida na fazenda, ao calcularem como grandes as chances de seu senhor poder, e, fundamentalmente, querer, impedir a prisão de todos eles, 0 que destruiria todo seu empreendimento econômico recente. A questão reside, então, entre perder poucos escravos para a cadeia e ter um prejuízo incômodo, alterando o ritmo de trabalho, assim como a ordem social na fazenda, ou sofrer o risco de prejuízos ainda maiores.

Ao analisarmos tais documentos nos deparamos com as dúvidas recorrentes de outros autores quando tratam das mudanças ocorridas a partir de 1850, com a intensificação do tráfico interno para o Sudeste. Vale lembrar que, com a influência das fortes secas que abalavam as já cambaleantes economias das províncias do Norte, na década de 1860, se comparadas às das províncias do Sul, o tráfico interprovincial de escravos ganhou novo fôlego, atraindo mais e mais escravos para o Sudeste. Isso elucida em parte o problema da intensificação dos processos criminais envolvendo escravos, na década de 1860. Esses escravos oriundos do Norte e os africanos e crioulos já estabelecidos no Sudeste tinham idéias de liberdade e costumes de trabalho em construção nas relações específicas com seus senhores e demais companheiros e homens livres, executando tarefas diferentes das que executariam nas fazendas de café. ${ }^{21}$ Estamos diante, então, de um novo elemento enfrentado pelos senhores e escravos do Sudeste, na formação das alianças e nas negociações de regras de trabalho, e mesmo nas "regalias" e formas de reivindicação na admissão de relações sociais aparentemente incompatíveis com uma sociedade escravista. ${ }^{22}$ 
Revista de Antropologia, São Paulo, USP, 2003, v. 46 № 1.

\section{Notas}

1 Agradecemos a leitura crítica e cuidadosa de Carlos Eduardo Moreira de Araújo e Rejane Valvano Corrêa da Silva, assim como as diversas conversas acerca das idéias e leituras aqui desenvolvidas com Flávio dos Santos Gomes, Ilmar Rohloff de Mattos, Peter Fry, Yvonne Maggie e Zílio Teixeira Tosta. Vale registrar que as reflexões apresentadas neste artigo são de inteira responsabilidade do autor.

2 Há autores que chamam atenção para as relações sociais dos escravos direcionadas a projetos de liberdade mais diretos e urgentes, operando com a idéia de protesto escravo envolvendo idéias de justiça social, em regras de trabalho formuladas no contato com senhores e feitores, reelaborando símbolos culturais africanos no Brasil. Por isso, também podemos assinalar que os trabalhos de Reis (1986) e Slenes (1999) são muito caros às idéias apresentadas neste texto. 0 primeiro, como um pioneiro trabalho metodológico sobre uma revolta escrava em suas relações sociais mais profundas, lendo a documentação criminal sobre a revolta como produto das autoridades que a reprimiu, e o segundo, revelando a ainda marcante influência cultural centro-africana entre os escravos do Sudeste, mesmo depois de 1850.

3 Segundo Castro, na segunda metade do século XIX, os senhores passaram a operar com um fator jamais existente até então, a perspectiva do final do trabalho escravo - mesmo sem uma data fixada. D essa forma, estariam se direcionando para "encaminhar de maneira mais segura as transformações do trabalho" (Castro, 1998, p. 210). Nos capítulos 9, "Sobre o poder moral dos senhores", e 10, "O fantasma da desordem", a autora apenas sinaliza as revoltas dos escravos assenzalados, e o medo das elites do Vale do Paraíba quanto às conseqüências do alastramento destas revoltas. Nossa pesquisa visa, recuando uma década, até 1860, estudar várias formas de protesto escravo na elaboração desses novos "acordos", e interpretar as atitudes dos senhores quanto ao final do tráfico.

4 Sobre o tráfico de escravos para o Sudeste, Florentino e Góes (1997) defendem, para a primeira metade do século X IX, que os senhores de escravos das fazendas de café do Sudeste tinham consciência das transformações que a compra de escravos poderia trazer na organização das senzalas. D essa forma, fariam políticas de desin- 
tegração dos laços sociais de solidariedade entre escravos, na construção ou não de familias, desde que a paz social estivesse mantida. Para os autores, isso realmente ocorreu, tendo continuação na intensificação do tráfico interno de escravos, depois de 1850. Entretanto, Slenes (1999) aponta para uma cultura africana de referências semelhantes no Sudeste a partir da qual, pela rota do tráfico internacional, formou-se uma "consciência de comunidade coletiva" nas fazendas de café, onde várias revoltas escravas ocorreram, tirando uma possível idéia de política senhorial eficaz pela paz social. Ver, também, Slenes (1991-1992). Nesse estudo, é mais adequado operarmos com a última posição.

5 Chalhoub (1990) trabalha com as intervenções dos escravos vindos das províncias do Norte, ainda nas casas de comissão, de negociações de compra e venda de escravos da Corte, para não irem às fazendas, pois assim ficaria mais difícil encontrar familiares e mesmo a adaptação ao novo tipo de trabalho. Proponho estudar o que aconteceu com os escravos vindos do Norte, no mesmo período, que realmente chegaram às fazendas e nelas trabalharam. Uma vez nelas, como se adaptaram e construíram as regras sociais com os escravos já estabelecidos e mesmo com os demais agentes sociais? Houve resistência dos escravos do Sudeste, criando uma resistência social para os recém-chegados? Se a idéia de Slenes (1991-1992) sobre a "protonação-banto" na região estiver certa, os códigos culturais africanos dos escravos vindos do Norte eram diferentes o bastante para que o impacto diante da sua chegada fosse maior ainda do que podemos pensar. Talvez tenhamos aí a pista para tantos processos criminais envolvendo esses dois grupos de escravos, entre 1860 e 1888.

6 Para uma grande avaliação crítica de como vários autores entenderam tal fato social histórico, para além de meras reconstituições históricas factuais, ver Reis (1988).

7 Sobre o funcionamento "mecânico estrutural" de uma fazenda de café escravista de um grande senhor do Sudeste, no período por nós estudado, ver Silva (1984, p. 135-83).

8 D ean (1977, p. 39-60) e Costa (1989, p. 153-348) talvez sejam os autores que chegaram mais perto dessas questões relativas à dinâmica da vida de um senhor de 
escravos de grandes lavouras do Sudeste cafeeiro, aspecto fundamental para o entendimento da vida social no Brasil daqueles anos do século X IX, porém ainda não trabalhado mais detalhadamente pelos estudos da sociedade imperial do café.

9 Wissenbach (1998, p. 13-59) trabalha com processos criminais de crimes cometidos por escravos, relativos à cidade de São Paulo, e discute as formas de serem tratados como ricas e imprescindíveis fontes documentais para o tema da escravidão. Trabalhando com a escravidão no ambiente rural, Machado (1987, p. 13-54) também é uma importante referência para o debate.

10 Sobre 0 "fato social" tratado por historiadores que bebem de análises e metodologias de investigação antropológicas, através das diferentes construções da realidade social pelos atores históricos, temos como referências Thompson (1966 e 1998) e D avies (1990). Como contraponto crítico a tal discussão, ver D esan (1992).

11 Sobre as relações sociais que levavam os escravos a fugirem de seus senhores, ver Silva (1989), Gomes (1996) e Araújo (2001).

12 É possível que escravos soubessem de seu preço no mercado, pautando a partir disso suas atitudes políticas com senhores e demais companheiros. Ver Slenes (1986).

13 Relações de autonomia escrava na condução de alguns aspectos de suas vidas podem ser encontradas em Slenes (1999) e Castro (1998). Sobre a importância cultural e política para os escravos do direito conquistado para cozinharem suas comidas, ver Joyner (1984).

14 Sobre a Corte de A pelação e os processos envolvendo escravos, no Rio de Janeiro, ver $\mathrm{G}$ rinberg (1994), apesar da autora ter trabalhado com a primeira metade do século XIX e nós trabalharmos com a segunda.

15 Sobre o medo das revoltas escravas, que tomariam grandes proporções quase em "efeito dominó" nas fazendas de café paulistas, ver Azevedo (1987); sobre as revoltas escravas na mesma região e no mesmo período, ver Machado (1994). 
16 Sobre tais formas de reivindicação de direitos adquiridos por trabalhadores nas lutas contra patrões e demais empregadores, e seus representantes na disciplina do trabalho, anteriormente ao século XX, ver Thompson (1998).

17 Sobre tais construções de solidariedade em casas de comissão de venda de escravos na Corte, no mesmo período, assim como a ingerência de escravos para tentar "escolher" os lugares e os senhores para onde seriam vendidos, ver Chalhoub (1990).

18 No que tange ao período e aos locais analisados neste artigo, Machado (1994) afirma que os senhores, necessitados de manterem os cativos num ritmo de trabalho mais forte pela falta de imediata substituição de mão-de-obra, conviveram com escravos demonstrando concepções de liberdade diversas, insubmissos às antigas regras de trabalho nos eitos, fugindo, abandonando seus senhores, matando-os para poder recolher de seus cofres prometidas cartas de alforria, enfim, aterrorizando a elite rural escravista paulista nos anos 1880. Concomitantemente, Machado analisa as múltiplas formas dos senhores, feitores e administradores encararem a escassez do número de cativos, nos diferentes modos de repressão das reivindicações escravas, ora tratando-os com severidade, ora fazendo 0 avesso disto.

19 Sobre o monopólio da violência pela classe senhorial, ver Mattos (1990). 0 autor aponta para uma certa continuidade da mentalidade dos senhores de escravos no Brasil quanto ao uso da violência, desde a colônia, fato que se fez presente no Império mesmo nas discussões políticas da classe dirigente, onde proprietários de terras, comerciantes e homens envolvidos com o lucro do comércio de escravos faziam-se fortemente presentes. Fundamentalmente, 0 autor entende a sustentação do Estado imperial brasileiro como síntese da dialética entre o trabalho escravo, lado bárbaro/ não-civilizado, e senhores de escravos e a boa sociedade, lado civilizado/moderno, da sociedade. Q uanto às deliberações das leis antiescravistas à desagregação da instituição escravista na sociedade brasileira, do ponto de vista dos debates políticos dentro da elite imperial, ver Carvalho (1996), Conrad (1978) e Costa (1989, p. 228-47). 
20 Há autores que avaliam, uns mais, outros menos, as relações entre direito, elite política e burocrática imperial e atitudes dos escravos diante desses debates político-jurídicos, que servem de suporte para este ponto. São eles, em ordem cronológica de publicação: Lamounier (1988), Grinberg (1994), Mendonça (1999), Rodrigues (2000), Pena (2001).

21 Tais questões estão presentes no prefácio à segunda edição de Costa (1989, p. 31-37).

22 A idéia de relações sociais e econômicas estranhas ou anômalas numa sociedade escravista é contestada com os conceitos de "contraponto escravo" e "transações sociais" por Morgan (1998, p. 377-418), que muito nos ajudaram a pensar a elaboração deste artigo. Agradecemos a Flávio dos Santos $\mathrm{G}$ omes a indicação deste texto.

\section{Referências bibliográficas}

ARAÚJO, C. E. M. de.

2001 A través dos tribunais: escravidão, cotidiano e criminalidade na província do Rio de Janeiro, século X IX . Rio de Janeiro, monografia de bacharelado, Departamento de História, UFRJ, p. 83.

AZEVED 0, C. M. M. de.

1987 O nda negra, medo branco: 0 negro no imaginário das elites, século X IX. Rio de Janeiro, Paz e Terra.

CARVALHO, J. M. de.

1996 Teatro de sombras: a política imperial. Rio de Janeiro, Editora da UFRJ/ RelumeDumará.

CASTRO, H. M. M. de.

1998 D as cores do silêncio: os significados da liberdade no Sudeste escravista - Brasil, séaulo X IX . Rio de Janeiro, Nova Fronteira. 
CHALHOUB, S.

1990 V isões da liberdade: uma história das últimas décadas da escravidão na Corte. São Paulo, Companhia das letras.

CONRAD, R.

1978 Os últimos anos da escravatura no Brasil (1850-1888). 2. ed. Rio de Janeiro, Civilização Brasileira.

COSTA, E. V. da.

1989 D a senzala à olônia. São Paulo, Brasiliense.

DAVIES, N.

1990 Culturas do povo: sociedade e cultura no início da França moderna. Rio de Janeiro, Paz e Terra.

DEAN, W.

1977 Rio Claro: um sistema brasileiro de grande lavoura, 1820-1920. Rio de Janeiro, Paz e Terra.

DESAN, S.

1992 Massa, comunidade e ritual na obra de E. P. Thompson e Natalie D avies. In: HUNT, L. (org.) A nova história altural. São Paulo, Martins Fontes, p. 63-92.

FLORENTINO, M. \& GÓES, J. R.

1997 A paz das senzalas: famílias escravas e tráfico A tlântico, Rio de Janeiro, c. 1790c.1850. Rio de Janeiro, Civilização Brasileira.

FOUCAULT, M.

1997 A arqueologia do saber. 5. ed. Rio de Janeiro, Forense-Universitária.

1999 A verdade e as formas jurídicas. 2. ed. Rio de Janeiro, NAU, Departamento de Letras, PUC/ RJ.

GOMES, F. dos S. 1996

Jogando a rede, revendo as malhas: fugas e fugitivos no Brasil escravista. Revista Tempo, Rio de Janeiro, 1(1), p. 67-93. 
GRINBERG, K.

1994 Liberata, a lei da ambigüidade: as açoes de liberdade da Corte de A pelação do Rio de Janeiro no séaulo X IX . Rio de Janeiro, Relume-D umará.

JOYNER, C. 1984

D own by the riverside: a South Carolina Slave Community U rbana. Illinois, University Press.

LAMOUNIER, M. L.

1988

D a escravidão ao trabalho livre: a L ei de L ocacão de Servigos de 1879. Campinas, Papirus.

LARA, S. H. 1988

Campos da violência: escravos e senhores na capitania do Rio de Janeiro, 17501808. Rio de Janeiro, Paz e Terra.

MACHAD 0, M. H. P. T.

1987 Crime e escravidão: trabalho, luta e resistência nas lavouras paulistas, 1820-1888. São Paulo, Brasiliense.

19940 plano e o pânico: os movimentos sociais na década da abolição. Rio de Janeiro/ São Paulo, Editora UFRJ/ Edusp.

MAGGIE, Y.

1992

M edo do feitico: relaçoes entre magia e poder no Brasil. Rio de Janeiro, Arquivo Nacional.

MATTOS, I. R. de.

1990

0 tempo saquarema: a formação do E stado imperial. 2. ed. São Paulo, Hucitec.

MEND ONÇA, J. M. N.

1999 Entre a mão e os anés: a L ei dos Sex agenários e os caminhos da abolição no Brasil. Campinas, Editora da Unicamp, CECULT.

MORGAN, P. D.

1998 Slave counterpoint: black culture in the eighteenth-century. Chesapeack and Lowcountry, The University of North Carolina. 
PENA, E. S.

2001 Pajens da casa imperial: jurisconsultos, escravidão e a L ei de 1871. Campinas, Editora da Unicamp, CECULT.

QUEIROZ, S. R. R. de.

1981

A abolição da escravidão. São Paulo, Brasiliense.

REIS, J. J.

1985

Rebelião escrava no Brasil: a história do levante dos malês (1885). São Paulo, Brasiliense.

1988 Um balanço dos estudos sobre as revoltas escravas na Bahia. In: REIS, J. J. (org.) E scravidão e invenção da liberdade: estudos sobre o negro no Brasil. São Paulo, Brasiliense, p. 87-140.

RODRIGUES, J.

20000 infame comércio: propostas e ex periências no final do tráfico de africanos para 0 Brasil (1800-1850). Campinas, Editora da Unicamp, CECULT.

SILVA, E.

1984 Barões e escravidão: três gerações de fazendeiros e a crise da estrutura escravista. Rio de Janeiro, Nova Fronteira/ Instituto Nacional do Livro.

1989 Fugas, revoltas e quilombos: os limites da negociação. In: SILVA, E. \& REIS, J. J. N egociação e conflito: a resistência negra no Brasil escravista. São Paulo, Companhia das Letras, p. 62-78.

SLENES, R. W.

1986

G randeza ou decadência? 0 mercado de escravos e a economia cafeeira da província do Rio de Janeiro, 1850-1888. In: COSTA, I. del N. Da. (org.) Brasil, história econômica e demográfica. São Paulo, IPE-USP, p. 103-55.

1991-1992 "Malungu, Ngoma vem!": África coberta e descoberta do [sic: leia-se "no"] Brasil. Revista U SP, São Paulo, n. 12, dez.-fev., p. 48-67.

1999 Na senzala, uma flor: esperanças e reoordaọoes na formação da família escrava, Brasil Sudeste, séaulo X IX . Rio de Janeiro, Nova Fronteira.

THOMPSON, E. P.

1966 The making of the E nglish working dass. New York, Vintage Books. 
1998 Costumes em comum: estudos sobre a cultura popular tradicional. São Paulo, Companhia das Letras.

WISSENBACH, M. C. C.

Sonhos africanos, vivências ladinas: escravos forros em São Paulo (1850-1880). São Paulo, Hucitec.

ABSTRACT: The author's main objective is to think the work relationships among slaveholders, slaves, peasants, administrators and foremen, in Southwest coffee farms, in the last decades of the slavery. Thereby, those social relationships are analyzed through two case studies; one of the most important topic is the conflict between free and slaves in formation of the alliances towards justice and work social rules, either being interrupts, or being restated in permanent social conflict.

KEYWORD S: Anthropology of slavery; emancipation; slave's politics; sociability in the farms. 